\title{
Da'wah Patterns through Local Culture of Gesrek Art in Kombongan Village, Garut Regency
}

\author{
Deni Miharja $^{1 *} \&$ Ipan Rifani ${ }^{2}$ \\ ${ }^{12}$ UIN Sunan Gunung Djati, Bandung, Indonesia \\ *denimiharja@uinsgd.ac.id
}

\begin{abstract}
The purpose of this study was to determine the art of Gesrek as a medium of cultural da'wah and the pattern of da'wah in the local culture of Gesrek art. The research was conducted in Kombongan Village, Pakenjeng Village, Pamulihan District, Garut Regency. The choice of this place was based on the growth and development of the art of Gesrek as one of the local pearls of wisdom of the Garut people. The research was conducted with a qualitative approach through descriptive methods. Where the researcher collects data through observation and in-depth interviews in order to be able to compare the data in the field and the literature review according to the research topic, the results showed that Gesrek art could be used as an effective cultural propaganda medium because this art contains practices that are following Islamic teachings both at the pre-implementation stage and at the time of implementation. The da'wah pattern of dialogue is a form of interaction between Islam and local culture in the art of Gesrek. This is marked by the content of the prayer and the behavior of the art following Islamic teachings and sharia, such as readings sourced from Al-Quran verses and rituals prior to their implementation that follow Islamic teachings.
\end{abstract}

Keywords; da'wah pattern; cultural da'wab; local culture; Gesrek, Art.

\begin{abstract}
ABSTRAK
Tujuan penelitian ini adalah untuk mengetahui seni Gesrek sebagai media dakwah kultural sekaligus pola dakwah dalam budaya lokal seni Gesrek. Penelitian dilakukan di Kampung Kombongan, Desa Pakenjeng, Kecamatan Pamulihan Kabupaten Garut. Pemilihan tempat ini didasarkan pada tumbuh dan berkembangnya kesenian Gesrek sebagai salah satu kearifan lokal masyarakat Garut. Penelitian dilakukan dengan pendekatan kualitatif melalui metode deskriptif. Di mana peneliti mengumpulkan data dengan teknik observasi dan wawancara mendalam, agar bisa membandingkan antara data di lapangan dan kajian literatur sesuai topik penelitian. Hasil penelitian menunjukkan bahwa seni Gesrek dapat dijadikan sebagai media dakwah kultural yang efektif, sebab kesenian ini mengandung praktik-praktik yang sesuai ajaran Islam baik pada tahap pra-pelaksanaan maupun pada saat pelaksanaan. Pola dakwah dialog menjadi wujud interaksi Islam dan budaya lokal yang terdapat dalam seni Gesrek. Hal ini ditandai dengan isi do'a dan perilaku kesenian tersebut sesuai dengan ajaran dan syariat Islam seperti bacaan-bacaan yang bersumber dari ayat AlQuran dan ritual-ritual sebelum pelaksanannya yang mengikuti ajaran Islam.
\end{abstract}

Kata kunci; pola dakwah; dakwah kultural; budaya lokal; Seni Gesrek.

Received: Oktober 2021. Accepted: November 2021. Published: Desember 2021. 


\section{INTRODUCTION}

Indonesia is a multicultural country consisting of various ethnic groups, customs, languages, and cultures. In Indonesia, each culture has a distinctive style that distinguishes it from other cultures. Indonesia is seen as a miniature of world civilization because of the variety of cultural riches. Local culture in Indonesia is the identity of the Indonesian nation, which is owned by most of the regions. Culture is the whole of thoughts and ideas resulting from human thought and their works in people's lives that are recognized and made their own from learning results (Koentjaraningrat, 2009: 165).

Practically, local culture has a lot to do with and even mixes with religious values. One of them, when local culture intersects with Islamic teachings. This gives rise to cultural dynamics closely related to the interaction and internalization of Islam in Indonesian society. The presence of Islam in Indonesia intersects with the ancestors' cultural heritage (Syukur \& Qodim, 2016). This causes acculturation between Islam and local culture. Acculturation of Islam and local culture marks the process of Islamization of Indonesian society. Acculturation is seen as a form of interaction between Islam and Indonesian culture. Thus, this process creates fundamental dynamics into a plural and multicultural social life (Miharja, 2014).

Auguste Comte (1958) viewed that human thought and development started from primitive society, then came to understand positivism. Gradually, humans use their reason (rationalism) as a source of truth. Furthermore, when the religious system develops, humans make religion a source of truth. In the Islamic perspective, absolute truth comes from Allah's revelations contained in the Qur'an and Al-hadith (Tohir \& Sahidin, 2019: 86). Islam respects the truth that develops in society that comes from culture. On this side, Islam as a religious system builds a compromise with local culture as a product of community culture. This compromise is carried out in cultural spaces that do not violate the main principles in Islam. Sociologically, acculturation of Islam and local culture is seen as an interaction between religious and cultural entities.

Koentjaraningrat (2009) states that culture is universal due to human ideas and works. Culture becomes a valuable entity in human life because it is applied through habituation and learning following the context and scope of life. Anthropologically, a culture is built up because of the seven 
elements of culture, namely: (1) a religious system; (2) community organizations; (3) knowledge; (4) language; (5) arts; (6) work; and (7) technology. All elements of culture have values to be used as guidelines for life.

The elements of culture are the needs that exist in humans and society. Based on its content and form, culture is divided into two parts, namely, material culture and non-material culture. Material culture is the result of human creativity that arises because of human feelings and desires. This culture is physical and has a size. This material culture includes things that are tangible in the senses. Meanwhile, non-material culture is the culture of creation, taste, and human will, which are hereditary customs, rules, and knowledge, such as art, habits, norms, etc. Non-material culture can be felt but cannot be touched by the senses.

The interaction of Islam and local culture in Indonesia takes place on a long historical trajectory. Islam places culture as a medium of da'wah in the internalization, diffusion, actualization, and transformation of Islamic teachings in society. Traces of cultural da'wah are evidenced by historical records showing mass religious conversions in the 15 th to 17 th centuries. The religious conversion from the ancestors' religion into Islam was brought by preachers in Indonesia (Amrun \& Khairiah, 2020).

Islam is not present as an eraser of local culture in society but places culture as a washilah for da'wah to disseminate Islam. Islam makes culture a channel for internalizing Islamic teachings. In this case, the interaction of Islam and local culture is built to display Islamic doctrine as a universal teaching. In practice, local culture is brought to life with the spirit of Islamic teachings. Islamic teachings serve as guidance that directs local culture to be following human and Islamic values (Aripudin, 2012; Aripudin, 2013; Wahid, 2018).

Acculturation of Islam and local culture is oriented towards realizing critical public awareness. In this case, Islam requires every human being to understand and be aware of placing culture as a space for da'wah's actualization. This awareness is built in the form of awareness so as not to be shackled by the traditional culture that is contrary to Islamic values. In addition, this awareness is also built through efforts to direct local cultures to contain the values of Islamic teachings (Ahmad, 2015).

The da'wah perspective views the interactional phenomenon of Islam and local culture as part of cultural da'wah, which is carried out through a cultural approach and in stages. Cultural da'wah is built on the cultural 
foundations of a heterogeneous, plural, and multicultural society. Cultural da'wah is designed through a series of da'wah activities that lead to gradual social change, where cultural da'wah is carried out by paying attention to, observing, and mapping the empirical conditions of the community, which are oriented to the development of life-based on Islamic values (Astori \& Librianti, 2015).

Practically, cultural da'wah is carried out through two approaches. First, da'wah is accommodative to local culture but still does not eliminate the substance of the values of Islamic teachings. Second, emphasizing the importance of culture as a medium and an object of da'wah, which is placed as a space for actualizing Islamic teachings (Sukayat, 2015: 110). Cultural da'wah is seen as necessary to disseminate and transform Islamic teachings in people's lives. Cultural da'wah places culture as a space for the actualization of Islam that must be filled and directed with Islamic values.

Historically, the intersection between Islam and local culture as a da'wah approach can be seen in the period of the Prophet's da'wah. How did the Prophet Muhammad place the culture of the people of the Arabian Peninsula at that time as an object and a medium of da'wah. This can be explained based on three approaches to the Prophet Muhammad's cultural da'wah to the Arab community, including: first, Islam was present as tahmil (accepting, perfecting, and continuing) the traditions and customs of the Arab community at that time; second, Islam is present as taghyir (accepting and reconstructing) the existing community values towards Islamic values; third, Islam is present as tahrim (rejecting and erasing) local culture which is contrary to Islamic values (Ummatin, 2014).

Studies on the interaction of Islam and local culture in da'wah's perspective have been conducted before. Muzaki's research (2017) observes Islamic da'wah through local cultural wisdom. It is concluded that the historical roots of Islamic da'wah in the archipelago began when the da'wah interpreters brought Islam into the midst of people's lives by utilizing culture. In this case, local cultural wisdom is placed as a da'wah strategy from a geostrategic point of view. M. Fuad Anwar (2018) described da'wah's phenomenology as a paradigm of socio-cultural science. It can be concluded that the phenomenology of da'wah is a da'wah pattern that pays attention to aspects of community understanding in the context of da'wah activities.

Alim Puspianto's research (2019) observes the phenomenon of intercultural da'wah in the cyber era. This study found that information and 
communication technology development should be used as a means of da'wah with a cultural approach. In other words, da'wah based on a cultural approach must be carried out by producing da'wah content disseminated in the digital space (cyberspace) — research by Rina Setyaningsih (2020), which observes the acculturation of Javanese culture as a da'wah strategy. The result is that the acculturation process of Javanese culture is expansive, where The values of religious teachings influence Javanese culture. At first, Hinduism and Buddhism dominated Javanese culture. This influence takes place in the daily activities of the community. When Islam came, Islam influenced Javanese culture, where culture is used as a medium of da'wah that influences the values and behavior of the community.

Research by Naufaldi Alif, Laily Mafthukhatul \& Majidatun Ahmala (2020) observes the acculturation of Javanese and Islamic culture through Sunan Kalijaga's da'wah. It was concluded that Sunan Kalijaga's da'wah was able to package Islam through the community's local culture so that Islam was quickly accepted and not forced. In practice, Sunan Kalijaga is seen as a syncretist of Islam and local culture, so that not a few express rejections through his da'wah. However, on the other hand, Sunan Kalijaga pays attention to the content of local elements in packaging his da'wah message. Research by Abdul Wahid (2021) photographed the interaction of cultural values in Islamic da'wah activities. It is concluded that the interaction of culture with da'wah is in the position of humans as both the subject and the object of da'wah. Islam is present as a religion that forms a model of Islamic culture. Namely, a cultural reality that is in line with Islamic values. Islam is used as a guide that directs human culture to live and develop following human nature based on religious values.

Other studies that specifically analyze the values of local cultural wisdom in the perspective of Islamic da'wah in several regions in the archipelago include research by Zulfa Jamalie and Muhammad Rifat (2012), which observes the Batamba tradition for the Banjar community; Mabrur Syah's research (2016) which observes Rejang culture as an acculturation of culture and religion in historical studies; Safriadi's research (2018) which observes the "Meurukon" tradition in Aceh as a cultural da'wah strategy; and research by Nur Ahmad and Fitria Muna (2019) which observed the collaboration of Sampak Gus Uran's religious da'wah in the cultural dialogue of Suluk Maleman.

Based on the above study, the researcher tried to examine the pattern of interaction between Islam and local culture in Gesrek art in Kombongan 
Village, Garut Regency. At first glance, the art of Gesrek can be said to be an art concept that has been built since time immemorial and is life-risking (bumbang pati). Gesrek art has long developed in Pamulihan sub-district, especially in Kombongan Village, Pakenjeng Village, Garut Regency. This art is similar to the Debus art from Banten. Several attractions in this art have a magical nuance. Gesrek art by its managers is often called the art of bubuang pati, which can also be interpreted as putting one's life on the line. However, this art is very religious. The prayers uttered by the Gesrek players also come from verses from the Qur'an.

The art called Gesrek is taken from the Sundanese language because it demonstrates how to play a weapon that is rubbed into the player's body. In addition, the term Gésrék stands for "Raihan Karuhun Art Movement." Today's players created this abbreviation because they see the history of this art is passed down from generation to generation. This Gesrek art has existed since before the 1950s and continues to be developed and passed down from generation to generation. In the researcher's view, Gesrek art displays an interactional form of culture and religion as a pattern of the da'wah approach in the community. This can be seen from the content of the elements of Gesrek art that contain the values of Islamic teachings in the form of prayer words and pieces of Al-Qur'an verses.

This study aims to find out how to build a pattern of interaction between the mystical art of gesrek and the rational pattern of Islam. In this case, this interactional pattern is reviewed based on cultural da'wah's perspective. Gesrek art is positioned as a medium and an object of da'wah. In addition, this review is carried out by observing cultural aspects that are accommodative to the values of Islamic teachings.

This study uses a qualitative approach with a descriptive method, which is a method that wants to describe based on in-depth field studies and literature. The findings obtained through observations and interviews were deepened descriptively with the support of studies from several research results either sourced from journals or books related to the research topic. So that, in the end, a pattern of cultural da'wah was found through the local culture contained in the art of Gesrek.

\section{RESULT AND DISCUSSION}

\section{The Concept of Interaction of Islam with Local Culture}

Islam developed in the archipelago took place in a long process. Historical records show an easy and non-coercive process of accepting Islam. Islam 
displays teachings that contain messages of peace and change. This process takes place through a community cultural approach that tends to be accommodating and compromise. Islam is present as teaching that displays the human dimension as conscious, rational, and not coercive. Because the character of Islam brings ease and peace in the archipelago, many people are willing to accept Islam as a way of life. In the cultural context, Islam intersects with previous religious teachings, which tend to be mystical and ancestral heritage (Taufik, 2013: 255-270). So, at this point, Islam places the previous culture and religion as an object and a medium of da'wah, which eventually undergoes acculturation.

Islamic symbols and culture influence each other. In practice, the symbols contained in these two are accommodative. Thus, giving rise to an approach model that shows the acculturation of religion and culture. Islam as a universal religion is permanent and eternal, while culture is relative and temporary (Miharja, 2013). Acculturation of culture and religion is seen as a necessity that has taken place in the history of Islamization in Indonesia. This acculturation also coincided with pre-Islamic religious teachings such as Hinduism and Buddhism, even values inherited from ancestors that displayed mysticism such as animism and dynamism.

Islam as universal religious teaching acts as an enlightener for humanity globally. Islam is also placed as a teaching that functions as a guide and carrier of the path of truth that Allah SWT blesses. The interaction of Islam and local culture occurs in the trajectory of Indonesian history. This is marked by the many cultural elements such as art and customs that display the acculturation of Islam and local culture. On the one hand, Islam is accommodative to local culture, but on the other hand, Islam critically rejects, reconstructs, and directs local culture to conform to religious values. This interaction takes place symbolically through a variety of multicultural cultures. This follows the rules in Islamic jurisprudence, which state that the interaction of Islam with local culture must pay attention to the maintenance of old values that are considered good according to religious standards and adopt new, better values (Syarifah, 2016).

Harmony between Islam and culture always has a point in common, therefore in dealing with life always with the will of Allah and humanity. Because of the interrelated interactions between Islam and that culture, religion impetus to a culture that remains in its path. In comparison, culture gives wealth to the religion that exists in society. These are mutually 
reinforcing and complementary to each other. Religion gives meaning and value to human life, while culture provides an attraction that has ethical and aesthetic values in human activities (Pals, 2011: 412). In this case, culture becomes a space for the actualization of human desires that have emerged along with the history of the development of human civilization.

Historically, the process of Islamization in Indonesia took place through cultural channels. This makes it easier for Islam to be accepted and used as a way of life by the people of Indonesia. Historical records show that there were mass religious conversions among the archipelago people in the 15 th to 17 th centuries. In this case, Islam brings peace and coolness that can be accepted by human reason. Thus, the traces of cultural da'wah carried out can deliver Islam to all corners of the archipelago (Amrun \& Khairiah, 2020).

The relationship between da'wah and culture is symbiotic. In this case, da'wah and culture both study humans with all their culture, humans as social beings, and humans as objects of da'wah both at the individual and group levels (Muzaki, 2017). Islam places humans as authorities who are aware of their actions, including concerning cultural activities. In this case, Islam places culture as a da'wah strategy that accommodates the values of local wisdom. The interaction of Islam with local culture takes place in two ways, namely (1) big culture, which is the concept of socio-cultural Islam, and (2) small culture is the concept of Islam in reality.

Da'wah with a cultural approach is carried out through a series of gradual activities. Where da'wah activities lead to changes in individuals and society, this change is based on the awareness gained through experience and adherence to existing values and norms. Awareness is obtained through open and dialectical dialogue (Anwar, 2018). Culture as an entity in society displays social symbols that contain certain expectations and historical contexts. Culture grows and develops due to creativity, initiative, and human feeling in life. Culture contains a set of social conventions of humans. The symbolic interaction of culture and Islam takes place both in the aspect of the mind (mindset), self (self), and social framework (society).

The sociological approach works to find information about religion and culture when it has become part of the real-life of the perpetrators (Kahmad, 2006: 88). The interaction process between Islam and culture can be accommodated by the values and customs of the local culture. The process of this accommodation is the 'mization of Islam,' as normative Islamic teachings are integrated into a culture without eliminating one side 
of the other. Indigenization of Islam is an interest that displays religious teachings that are tolerant. Where indigenization strengthens religious and cultural accommodation, this term refers to efforts to interact with Islam and culture that mutually reinforce each other in several aspects without mixing Islamic values into cultures that are seen as contradictory to Islamic teachings.

Islam together with local culture in society (local culture) into a single unit that is complimentary. In this case, the model of cultural da'wah carried out by the prophet Muhammad SAW can be used as an example in the process of interaction between Islam and culture. In which, there are three models of approach, namely: first, Islam was present as tahmil (accepting, perfecting, and continuing) the traditions and habits of Arab society at that time; second, Islam is present as taghyir (accepting and reconstructing) the existing community values towards Islamic values; third, Islam is present as tahrim (rejecting and erasing) local culture which is contrary to Islamic values (Ummatin, 2014). In this case, the concept of interaction between religion and local culture places religion as primary, while culture is secondary (Wahid, 2001: 111). In other words, religion (especially Islam) is seen as definite and unchanging teaching, while culture allows for changes and the development of human civilization.

\section{The pattern of Interaction of Islam with Local Culture}

Cultural elements consist of two parts, namely significant elements and minor elements. Large cultural elements are cultural elements that are easy to change, while small cultural elements are cultural elements that are difficult to change. Cultural elements that are easy to change include art, language, and technology. Meanwhile, elements that are difficult to change include religion (belief), social institutions, and science (Sumpena, 2012). The interaction between the two is complementary and continuous. Where cultural elements are large and small, both display the reality of a human culture that grows and develops and is used as a guide in their daily activities.

Islam entered Indonesia with significant development. Islam entered through cultural interactions that influence each other. Ideologically, the interaction of Islam in human culture displays the relationship between humans and God (hablu minallah) and humans and humans (hablu minannas) (Nasution, 2003: 4). In the interaction process, the local culture experienced a blend of Islam. The combination of the two is called cultural 
acculturation. Acculturation is a mixture of two or more cultures that meet and influence each other or the process of entering foreign cultural influences in society, some of which absorb selectively from existing cultural elements. Thus, in the meeting of two different cultures, not all cultural elements that enter are rejected, and also, not all cultural elements can be fully integrated (Abubakar, 2016).

The combination of Islamic and cultural entities can lead to a tug-ofwar process, thus encouraging compromises in adaptation or accommodation and assimilation. A cultural element in the interaction process will be rejected if there is a striking conflict with local values. These conflicting elements can be accommodated if modified according to the prevailing culture. In addition, it can also be done through reinterpretation so that the new elements can be accepted. Every culture can survive and select outside cultural influences in rejection or silence, accommodation, or integration of foreign cultures into the original culture.

The interaction of Islam with the local culture can be seen from the patterns that occur, both in conflict, adaptation or accommodation, assimilation, and integration. Conflict and integration can produce a combination of each cultural value to achieve a unique culture with a local image. This is possible to be realized because humans shape, make use of, and change the things that best suit their needs in every encounter between two cultures. The process of cultural acculturation gave birth to local genius, namely the ability to absorb, select, and actively cultivate the influence of the culture that came.

Sociohistorically, the interaction of Islam with local culture in Indonesia occurs through three patterns of spreading and forming Islamic formations. This also refers to historical records that show Islamization in Southeast Asia. The three patterns include:

First, the Pasai pattern is a pattern in which Islam grows together with the center of state power development. Islam becomes the sociopolitical foundation of the state, as explained in the saga of the kings of Pasai. Second, the pattern formulated based on the cases of Malacca, Patani, Gowa-Tallo, and Ternate is known as the Malacca Pattern. This pattern shows the process of spreading and accepting Islam through magical or other powers that occur through converting local power centers into Islamic power. Furthermore, third, the Javanese pattern, namely the spread of Islam that occurred through the conquest of local power centers (Majapahit) by Islam (Demak), including the Sriwijaya (Buddhist) Kingdom 
in South Sumatra.

The spread and formation of Islam occurred in two new patterns, namely the integrative pattern and the dialogue pattern. The pattern of Pasai and Malacca is called the integrative pattern, which is a tendency that points towards the formation of an integrative pattern of tradition. Integrative is the adjustment stage reached at a certain point or moment in the culture continuum (Abdullah \& Shiddiue, 1989: 81). Conceptually and structurally, the interaction between Islam and local culture is carried out through indigenizing Islamic teachings. In this case, Islam becomes an intrinsic part of the overall cultural system. Islam is seen as the foundation of society, culture, and personal life.

Meanwhile, the Javanese pattern is called the dialogue pattern, namely the emergence of a specific tradition (local and Islamic dialogue traditions). Dialogue patterns can lead to conflict and harmony. However, if a conflict occurs, Islam and local culture do not form a harmonious and static relationship. Meanwhile, if harmony occurs, Islam and local culture form a harmonious and dynamic relationship. Thus giving birth to Islamic traditions with a local image. Indonesia has a variety of indigenous cultures that are acculturated with foreign cultures without losing their original culture (Solihin, 2003: 169).

The integrative pattern is often referred to as the Islamization pattern, while the dialogue pattern is called the indigenization pattern. The reality of the interaction of Islam with local culture in a community will always be unique. This is because acculturation with local culture forms a separate system different from the systems and methods found in other Islamic societies. Although each group embraces the same religion and belief, each region has its system and method and Islamic characteristics. This shows that religion is born in a cultural system because humans expect other powers to be able to answer their limitations (Perseun, 1988: 35).

Placing culture as a medium of da'wah can be viewed from two sides: the fact that Islam spreads in Indonesia, which is readily accepted and without coercion, and the existence of Islamic values in local culture (Ummatin, 2014). These two aspects indicate an integrative interaction between Islam and local culture. Islamization takes place within the scope of human culture that develops evolutionarily, along with the development of human civilization to date. The integration pattern of Islam and the local culture has dynamic ups and downs. Where Islam develops through a series of da'wah patterns that occur in conflict, accommodation, and adaptation. 
Therefore, the model of cultural da'wah that is tahmil, taghyir, and tahrim occur in Islamizing Indonesian society. This is a manifestation of the interaction pattern of Islam and local culture in an integrative and dialogical manner.

\section{Gesrek Art as a Cultural Da'wah Media}

Gesrek art is one of the arts in Garut Regency, precisely in Bojongboléd Village, Garumukti Village, Pamulihan District. Gesrek art is a performing art in weapons performances. The art called Gesrek is taken from the Sundanese language because it demonstrates how to play a weapon that is rubbed into the player's body. In addition, the term Gésrék stands for "Raihan Karuhun Art Movement." The current players make this abbreviation because they see aspects of the history of this art that are passed down from generation to generation. Gesrek art has existed since before the 1950s. In the 1970s, the art of Gersrek was introduced by Abah Sanuhri to Garumukti Village. A year later, in the 1980s, this art was passed down to Abah Usup as an elder of Gesrek art. Furthermore, in 2002, the art of Gesrek was passed on to the next generation, namely Aki Mimin Suparman, who has been one of Abah Sanuhri's children until now. The arts began to develop and become known to rural communities.

The things that must be considered for the performing arts are (1) the facilities used in the ritual such as garlic, rice, water, seven kinds of flowers, young coconut, eggs, brown sugar, coffee, incense, refined coconut oil, panglay, salad, and smoking; and (2) tools used in performing arts, such as the Qur'an, Barzanzi books, bamboo, machetes, fuel, trumpets, drums, gamelan, and costumes. The practice of Gesrek performing arts is divided into two stages, namely the pre-implementation and implementation stages. The stages before the implementation are to perform the ritual, start, introduce the weapon (put a spell on the weapon), and make a circle. While on stage, performing arts performances, including Pencak silat, machete weapons, broken bamboo, and art performances in a fire trance. At the show's end, the players move around while playing weapons and are accompanied by prayers. Occasionally reading prayers and always absorbed by satire that contains advice, recitation, and grace.

Gesrek art has long developed in Pamulihan sub-district, especially in Kombongan Village, Pakenjeng Garut Village. This art is similar to the Debus art from Banten. Several attractions in this art have a magical nuance. Gesrek art by its managers is often called the art of bubuang pati, 
which can also be interpreted as putting one's life on the line. However, this art is very religious. The prayers that Gesrek players say come from verses of the Qur'an.

The word 'Gesrek' is most likely taken from the attractions being played. 'Gesrek' or 'Pagesrek' in Sundanese means two complex objects rubbing against each other. When showing their magic, the players deliberately rub various hard and sharp objects such as machetes or other weapons on their bodies. Because their bodies are immune, sharp objects cannot injure the body, only 'pagesrek.'

The Gesrek players usually consist of ten people. These players are also called machetes, where they are assisted by 4 to 7 people whose job is to provide equipment and maintain the show's security. Usually, this art is accompanied by a pendulum. One day before the show, the head of this art must prepare offerings in the form of young coconut, eggs, rujak, sour salad, coconut salad, mas banana, tumpeng rice, and cigars. At the show, the necessary equipment must be held first and then given a mantra or prayer so that God will give salvation.

After the prayer was read, a player came in and performed the Pencak silat moves. A moment later, this player will possess a spirit and perform fast, tense, and scary movements. If this is the case, the other players will enter the arena while doing the same.

The head of the art of Gesrek again chanted spells so that the spirits that possessed the players came out immediately. Gesrek players will regain consciousness, then the tools that have been previously held will be "weakened." The initially sharp machete became blunt, or the hard one became soft. After that, the instrument sounded accompanied by the prayer of the prophet. Then began the attractions that resembled a debus showfor example, stabbing the stomach with a machete, hitting the head with bamboo, or rolling over hot coals.

This art often displays insignificant celebration activities such as Augustus (Indonesian Independence Day) or is deliberately invited by certain people to enliven various events. Until now, several art groups have had the potential to be used as cultural tourism. This art has become a hereditary culture, especially in Kombongan Village.

The implementation of Gesrek art is often carried out annually or at indefinite times. For example, at an annual or scheduled time, namely to commemorate the anniversary of Garut Regency and the Independence Day of the Republic of Indonesia. Other times that are not celebrations, 
circumcisions, and other cultural events. Until now, Gesrek art has received appreciation from various groups, both from the Government and the community. Where the art of Gesrek is seen as an ancestral cultural heritage that must be preserved and become local wisdom for the people of Garut.

The da'wah perspective views the art of Gesrek as an effective da'wah media that can be used to spread Islamic values. This is based on the reality that in the stage of implementing the art of Gesrek, the chairman and the performers recite prayers or mantras that originate from Islamic teachings. In addition, when the show is held, the performers of Gesrek are accompanied by prayers as a form of hope and praise to Allah and the Prophet Muhammad.

Gesrek art can be seen as a medium of cultural da'wah. However, in certain aspects, things related to magical elements are still dominant, so it becomes a challenge for da'wah activists to direct the art of Gesrek to the values of Islamic substance that are following the foundations of Islamic faith, worship, and morals. The use of specific tools as offerings used to summon certain spirits shows that the aspects of superstition, heresy, and superstition are still dominant in this art. At this point, the pattern of interaction between Islam and the art of Gesrek must be directed in a more focused manner so that it leads to essential Islamic values. So, Gesrek art can be used as a medium of cultural da'wah.

In the process of da'wah, Islam upholds local wisdom as long as it does not conflict with the central message of Islamic teachings in terms of faith, worship, and morals. The relationship between Islam and culture goes hand in hand with human civilization. In this case, culture as a medium of da'wah brings together Islamic messages with community culture (Wahid, 2021). Islam does not erase local culture as long as its substance does not conflict with Islamic teachings. Likewise, Islam perfects and continues local culture if it contains good values following Islamic teachings.

Through a cultural approach, Da'wah requires the ability of a da'i to read the empirical conditions of madh'u while also utilizing cultural means as an effective da'wah medium (Puspianto, 2019). This approach views that the success of a cultural da'wah activity is highly dependent on the ability of the preacher to capture the needs and take advantage of the public's attraction to an object or facility.

Gesrek art is an effective da'wah media whose existence must be utilized by da'wah interpreters to display Islamic messages. Thus, cultural values that still dominate this art and are seen as contrary to Islamic 
teachings can be minimized or directed to conform to the substantive values of Islamic teachings because Gesrek art has significant social capital to serve as a medium for cultural da'wah. At the same time, it can be used as a space for the actualization and collaboration of religion and culture so that they do not conflict and often lead to conflict in the community. In this position, the interaction of Islam and local culture in the art of Gesrek must be directed in an integrative way to display the universality of Islam that revives local culture with religious values that save and pacify the community.

\section{Dialogue Da'wah Patterns in the Art of Gesrek}

Theoretically, cultural forms in Gesrek art are ideas that include theoretical values, religious values, aesthetic values, social values, and economic values from various forms of activity. This can be seen from implementing Gesrek art both before the performance (preparation) and during the performance. There are forms of offerings in the art of Gesrek which include garlic, rice, seven kinds of water, flowers, eggs, coffee, incense, oil, panglay, cigarettes, the Qur'an, the book of Barzanji, bamboo, machete knives, (sesepuh machetes) fuel, trumpets, needles, gamelan, and costumes. Meanwhile, the function of Gesrek art itself is a cognitive function, aesthetic function, recreational function, value function, and didactic function. This is related to Gesrek art performances that display specific values in terms of culture and religion (Koentjaraningrat, 2009).

The da'wah perspective views the art of Gesrek as a medium of cultural da'wah that contains specific Islamic messages. Where the art of Gesrek grows and develops in the community as a form of spirituality that is displayed in ethical and aesthetic values, this can be seen from the recitation of specific prayers that are sourced from the verses of the Qur'an as a performance accompaniment prayer. This prayer is recited in the hope of getting salvation from Allah SW'T.

Gesrek art shows the interaction pattern between Islam and local culture in dialogue. Dialogue patterns can lead to conflict and harmony. However, if a conflict occurs, Islam and local culture do not form a harmonious and static relationship. Meanwhile, if harmony occurs, Islam and local culture form a harmonious and dynamic relationship. So that gave birth to the Islamic tradition with a local image (Solihin, 2003). This is marked by the emergence of Gesrek art, which often results in conflicts in society because it is contrary to Islamic teachings. Nevertheless, it is also 
starting to be accepted as art that contains Islamic values.

Some of the Islamic values that appear in the art of Gesrek include: First, the Nature of Life. It contains about how to deal with life so as not to be sad and not worry. Must try to make his life better and get the salvation of this world and the hereafter. Second, the Nature of Work. It contains information that shows that the existence of friction art is due to the Creator's existence. It means that the art of gesrek is the work and property of the people of Garumukti Village and provides leadership to the people of Garumukti Village as people who are still studying their ancestral culture and passed down from generation to generation in the Kombongan village. Third, the nature of the human role in space and time. The purpose of this is regarding the certainty of the degree of the art of gesrek from time to time passed down from generation to generation in order to show that the art of gesrek is a work of art created from the past for people in the future who will not forget the traditions of their ancestors.

Fourth, the nature of human relations with the natural surroundings. It shows that humans as creatures of God have a more significant, higher, and nobler role than other creatures. Fifth, the nature of human relationships with peers means that every human being is always there and needs each other and cannot live alone individually. And Sixth, the essence of the relationship with Allah SWT. That humans do not forget the grace of the creator, the creator. The nature of his closeness to Allah is prioritized because the art of friction is more devoted to Him.

These six Islamic values are seen as intrinsic messages contained in the art of Gesrek. Gesrek art as a medium of cultural da'wah can be developed and preserved to become a social force that can display the friendly face of Islam with local culture. In this case, the interaction of Islam and local culture in the art of Gesrek is a dialogue that aims to build the harmonization of Islam and culture as a universal religion. Gesrek art shows the existence of a local wisdom-based da'wah pattern that brings Islamic values to life in the culture of the community. Gesrek art contains life teachings that must be based on Islamic values to critically place humans as subjects and objects of da'wah and culture.

\section{CONCLUSION}

In general, we can conclude that the character education program in Gesrek art is one of the arts in the Garut district. Precisely in Kombongan Village, Pakenjeng Village, Pamulihan District, Garut Regency. Gesrek art 
puts its life at stake by using sharp objects or other complex objects, such as machetes and bamboo. Gesrek art is taken from the Sundanese language, which means "Raihan Karuhun Art Movement," abbreviated as Gesrek Art. Today's players created this abbreviation because they saw the history of art passed down from generation to generation. This art has existed since before the 1950s and continues to grow to be known by people in rural and urban areas.

Things that must be maintained in this Gesrek art are prayers, prayers, and sentences from the Qur'an. In comparison, the goods and forms of offerings that need to be directed to contain Islamic values in the process of their use include garlic, rice, seven kinds of water, flowers, eggs, coffee, incense, oil, panglay, cigarettes, the Qur'an, the book of Barzanji, bamboo, machete blades, fuel (sesepuh machetes), trumpets, woven sewing needles, gamelan, and player costumes.

The implementation of Gesrek art is divided into two stages, namely pre-implementation and implementation. Prior to the implementation, this art begins with reading prayers of a religious nature, looting the graves to pray for elders, fasting one day within a year, both obligatory and voluntary, having ablution before carrying out the performance. Meanwhile, the implementation begins with the tools that have been provided, such as performance tools and Pencak silat movements.

The thing that makes the pattern of interaction between Islam and local culture is dialogue is the content of prayer and the behavior of the arts following the teachings and Islamic law that have been determined. Such as readings that are sourced from verses of the Qur'an, rituals prior to their implementation that follow Islamic teachings, and their actions which include Islamic art. This pattern of dialogue da'wah makes Gesrek art a medium of cultural da'wah that is accepted by the community and social capital in building religious and cultural harmonization.

\section{REFERRENCES}

Abdullah, T., \& Shiddiue, S. (1989). (Ed) Tradisi Kebangkitan Islam Di Asia Tenggara. Jakarta: LP3ES.

Abubakar, F. (2016). Tradisi Islam Dengan Budaya Lokal Dalam Tradisi Khanduri Maulod Pada Masyarakat Aceh, Akademika: Jurnal Pemikiran Islam, 21(1), 19-34. https://ejournal.metrouniv.ac.id/index.php/akademika/article/view/453. 
Ahmad, N. (2015). Mewujudkan Dakwah Antar Budaya dalam Perspektif Islam, At-Tabsyir: Jurnal Komunikasi Penyiaran Islam, 3(1), 21-40. https://journal.iainkudus.ac.id/index.php/komunikasi/article/view 1639.

Ahmad, N., \& Muna, F. (2019). Kolaborasi Dakwah Religi Sampak Gus Uran Dalam Dialog Budaya Suluk Maleman, At-Tabsyir: Jurnal Komunikasi Penyiaran Islam, 6(2), 383-398. DOI: http://dx.doi.org/10.21043/at-tabsyir.v6i2.6891.

Alif, N., Mafthukhatul, L., \& Ahmala, M. (2020). Akulturasi Budaya Jawa dan Islam melalui Dakwah Sunan Kalijaga, Al-a'dalah, 23(2), 143-162. https://doi.org/10.35719/aladalah.v23i2.32.

Amrun, J., \& Khairiah. (2020). Jejak-Jejak Dakwah Budaya: Konversi Agama Massal di Asia Tenggara abad XV-XVII, Idarotuna: Jurnal Kajian Manajemen Dakwah, 2(2), 34-43. DOI: http://dx.doi.org/10.24014/idarotuna.v2i2.9554.

Anwar, M. F. (2018). Fenomenologi Dakwah (Dakwah dalam Paradigma Sosial Budaya), Jurnal Empower: Jurnal Pengembangan Masyarakat Islam, 3(2), 97-111. DOI : 10.24235/empower.v3i2.3512.

Aripudin, A. (2012). Dakwah Antar Budaya. Bandung: Remaja Rosda Karya. Aripudin, A. (2013). Sosiologi Dakwah. Bandung: Rosda Karya.

Astori, A. K., \& Librianti, E. O. I. (2019). Dakwah Kultural: Relasi Islam dan Budaya Lokal, Ath-Thariq: Jurnal Dakwah dan Komunikasi, 3(2), 169-178. DOI: https://doi.org/10.32332/ath_thariq.v3i2.1548 .

Comte, A. (1958). The Positive Philosophy of Auguste Comte. Diterjemahkan oleh Harriet Martineau. New York: Calvin Blancahard.

Jamalie, Z., \& Rifat, M. (2012). Dakwah Kultural: Dialektika Islam dan Budaya dalam Tradisi Batatamba, Alhadharah: Jurnal Ilmu Dakwah, 11(21), 61-76.

DOI: http://dx.doi.org/10.18592/alhadharah.v11i21.1786.

Kahmad, D. (2006). Sosiologi Agama Cet Ke-4. Bandung: Remaja Rosdakarya.

Koentjaraningrat. (2009) Pengantar Ilmu Antroplogi. Jakarta: PT Rineka Cipta. Miharja, D. (2013). Adat, Budaya Dan Agama Lokal, Studi Gerakan Ajeg Bali Agama Hindu, Kalam, 7(1), 53-78. DOI: https://doi.org/10.24042/klm.v7i1.444.

Miharja, D. (2014) Persentuhan Agama Islam Dengan Kebudaya Asli Indonesia, Miqot, 38(1), 189-214.

Muzaki. (2017). Dakwah Islam dan Kearifan Budaya Lokal, Orasi: Jurnal 
Da'wah Patterns through Local Culture of Gesrek Art in Kombongan Village, Garut Regency

Dakwah dan Komunikasi, 8(1), 38-49.

https://syekhnurjati.ac.id/jurnal/index.php/orasi/article/view/164 $2 / 1240$.

Nasution, H. (2003). Pembaharuan Dalam Islam Sejarah Pemikiran Dan Gerakan. Jakarta: PT. Bulan Bintang.

Pals, D. L. (2001). Seven Theories Of Religion. Yogyakarta: Qalam.

Perseun, V. (1988). Strategi Kebudayaan. Yogyakarta: Kanisius.

Puspianto, A. (2019). Dakwah Antar Budaya di Era Cyber, An-Nida': Jurnal Prodi Komunikasi Penyiaran Islam, 7(2), 95-116. http://ejurnal.stail.ac.id/index.php/annida/article/view/17.

Safriadi. (2018). Dakwah Kultural dalam Budaya "MEURUKON" di Aceh, Jurnal Bimas Islam, 11(2), 225-248. DOI: https://doi.org/10.37302/jbi.v11i2.52.

Setyaningsih, R. (2020). Akulturasi Budaya Jawa sebagai Strategi Dakwah, Riayah: Jurnal Sosial dan Keagamaan, 15(1), 73-82. https://ejournal.metrouniv.ac.id/index.php/riayah/article/view/2304.

Solihin, M. (2003). Prinsip-Prinsip Dasar Pemikiran Keislaman. Bandung Pustaka Setia.

Sukayat, T. (2015). Ilmu Dakwah. Bandung: Simbioasa Rekatama Media

Sumpena, D. (2012). Islam dan Budaya Lokal: Kajian terhadap Interelasi dan Budaya Sunda, Ilmu Dakwah: Academic Journal for Homiletic Studies, 6(1), 101-120. https://journal.uinsgd.ac.id/index.php/idajhs/article/view/329.

Syah, M. (2016). Akulturasi Islam dan Budaya Lokal Kajian Historis Sejarah Dakwah Islam di Wilayah Rejang, Jurnal Dakwah dan Komunikasi, 1(1), 21-43.

http://journal.iaincurup.ac.id/index.php/JDK/article/view/77/28. Syarifah, M. (2016). Budaya dan Kearifan Dakwah, al-Balagh: Jurnal Dakwah dan Komunikasi, 1(1), 23-38.

http://ejournal.iainsurakarta.ac.id/index.php/al-

balagh/article/view/43/27.

Syukur, A., \& Qodim, H. (2016) Islam, Tradisi Lokal, dan Konservasi Alam: Studi Kasus Di Kampung Dukuh Kabupaten Garut, Kalam, 10(1), 139-166. DOI: https://doi.org/10.24042/klm.v10i1.339.

Taufik, M. (2013) Harmoni Islam Dan Budaya Lokal, Jurnal Ilmiah Ilmu Ushuluddin, 12(2), 255-270. https://jurnal.uinantasari.ac.id/index.php/ushuluddin/article/view/692.

Tohir, A., \& Sahidin, A. (2019). Filsafat Sejarah: Profetik, Spekulatif, Dan 
Kritis. Jakarta: Prenadamadina Group.

Ummatin, K. (2014). Tiga Model Interaksi Dakwah Rasulullah terhadap Budaya Lokal, Jurnal Dakwah: Media Komunikasi dan Dakwah, 15(1), 179-205. http:/ / ejournal.uinsuka.ac.id/dakwah/jurnaldakwah/article/view/303/282.

Wahid, A. (2001). Pergulatan Negara, Agama Dan Kebudayaan. Jakarta: Desantara.

Wahid, A. (2018). Dakwah dalam Pendekatan Nilai-Nilai Kearifan Lokal (Tinjauan dalam Perspektif Internalisasi Islam dan Budaya), Jurnal Dakwah Tabligh, 19(1), 1-19. http://journal.uinalauddin.ac.id/index.php/tabligh/article/view/5908/5109.

Wahid, A. (2021). Memotret Interaksi Nilai-nilai Budaya dalam Aktivitas Dakwah, Retorika: Jurnal Kajian Komunikasi dan Penyiaran Islam, 3(1), 86-101. DOI: https://doi.org/10.47435/retorika.v3i1.656_. 